\title{
Assessment of dynamic and long-term performance of an innovative multi-story timber building via structural monitoring and dynamic testing
}

\author{
Piotr Omenzetter ${ }^{*}$, Hugh Morris ${ }^{\mathrm{a}}$, Margaret Worth ${ }^{\mathrm{a}}$, Andrew Gaul ${ }^{\mathrm{a}}$, Simon Jager ${ }^{\mathrm{a}}$, Yohann \\ Desgeorges $^{\mathrm{a}}$ \\ ${ }^{a}$ The University of Auckland, Private Bag 92019, Auckland, New Zealand
}

\begin{abstract}
An innovative three-story timber building, using self-centering, post-tensioned timber shear walls as the main horizontal load resisting system and lightweight non-composite timber-concrete floors, has recently been completed in Nelson, New Zealand. It is expected to be the trailblazer for similar but taller structures to be more widely adopted. Performance based standards require an advanced understanding of building responses and in order to meet the need for in-situ performance data the building has been subjected to forced vibration testing and instrumented for continuous monitoring using a total of approximately 90 data channels to capture its dynamic and long-term responses. The first part of the paper presents a brief discussion of the existing research on the seismic performance of timber frame buildings and footfall induced floor vibrations. An outline of the building structural system, focusing on the novel design solutions, is then discussed. This is followed by the description of the monitoring system. The analysis of monitoring results starts with a discussion of the monitoring of long-term deformations. Next, the assessment of the floor vibration serviceability performance is outlined. Then, the forced vibration tests conducted on the whole building at different construction stages are reviewed. The system identification results from seismic shaking records are also discussed. Finally, updating of a finite element model of the building is conducted.
\end{abstract}

Keywords: Timber structures, structural health monitoring, dynamic testing, dynamic response, seismic response, model updating, system identification, floor vibrations

\section{INTRODUCTION}

Modern multistory timber buildings, six to nine stories high, have been constructed in countries including Germany, England, Canada and Sweden. An example of this trend is the construction of an innovative three-story office structure, using self-centering, post-tensioned timber shear walls as the main horizontal load resisting system and lightweight noncomposite timber-concrete floors, recently completed in New Zealand for the Nelson Marlborough Institute of Technology (NMIT). The preliminary design concept won a funding contribution from the New Zealand Ministry of Agriculture and Forestry (MAF) in competition for a timber government building of a commercial scale. The project is expected to be the trailblazer for similar, possibly taller, structures to be more widely adopted locally.

Performance based design requires the understanding of structural responses to the various loads acting on structures. Insitu, full-scale structural monitoring and testing can provide invaluable insights and help avoid the many simplifications and assumptions present in analytical or numerical simulations and laboratory experimentation. Modest MAF funding was obtained to install permanent instrumentation into the building investigating several aspects of structural performance relevant for timber structures in a strong seismic and wind environment. One-off, ambient and forced dynamic tests were also conducted. Dynamic performance of floors due to occupant induced vibrations is also being monitored. A separate monitoring system collects data on long-term timber element deformations as well as temperature and humidity.

The outline of this paper is as follows. Firstly, a brief literature survey is included that highlights previous research attempts aiming at a better understanding of the issues in dynamic performance of timber frame buildings. Issues in footfall induced vibrations of lightweight floors and their monitoring are also covered. Then, the NMIT building and its

*p.omenzetter@auckland.ac.nz; phone 649 923-8138; fax 649 373-7462; www.auckland.ac.nz 
Return to your MySPIE To Do List at http://myspie.org and approve or disapprove this submission. Your manuscript will not be published without this approval. Please contact author_help@spie.org with any questions or concerns.

structural systems are described with the focus on the seismic and wind load bearing shear walls and non-composite timber-concrete floors. The comprehensive monitoring system designed for the building and comprising sensors to measure both long-term and slowly varying timber deformations due to creep and temperature and humidity variations, as well as dynamic responses produced by wind, ground shaking and, in case of floors, footfall is described. The results from the monitoring of long-term effects and behavior are discussed. Next, the assessment floor vibration serviceability performance is outlined. Then, the forced vibration tests conducted on the whole building at different construction stages are reviewed. This is followed by system identification results from seismic shaking records. Finally, finite element (FE) model updating is conducted.

\section{LITERATURE REVIEW}

This section presents a literature review that surveys existing research into the dynamic performance of timber frame buildings and footfall induced vibrations of lightweight floors - two topical areas that the dynamic monitoring system of the NMIT building is targeting for real-life data.

\subsection{Dynamic performance of timber frame buildings}

Strong earthquakes, such as the 1994 Northridge earthquake and the 1995 Kobe earthquake exposed the vulnerabilities of timber frame structures. These were attributed to the lack of adequate performance based design procedures for timber ${ }^{1}$. Such procedures need to draw on full-scale experimental data, however, few full-scale seismic tests have been conducted to date on multistory light-frame timber buildings and even less on medium to heavy-frame buildings ${ }^{2}$. Some representative tests and their conclusions are reviewed below with emphasis on the influence of non-structural elements on seismic response and amplitude dependence of natural frequencies and damping.

Filiatrault et al. $^{3}$ performed uni-axial shake table tests on a near full-scale two-story light-frame timber building. The building was tested as the bare frame and then with interior and exterior finishings. The fundamental frequency of the building was found to be dependent strongly, a decrease by $40 \%$, on the presence of non-structural elements. Viscous damping for the structure with finishing materials was found to be $7 \%$. The simple structure including finishing materials displayed a near linear response.

Camelo ${ }^{4}$ conducted a series of ambient and forced vibration tests on existing multistory light-frame timber houses with different configurations and heights. Fundamental frequencies found from ambient vibrations were shown to be higher than those obtained from the forced vibration tests; this was attributed to amplitude dependence of modal frequencies. An analysis of the data from the shake table tests performed by Filiatrault et al. ${ }^{3}$ showed a large discrepancy in the damping estimates, with $15 \%-20 \%$ critical damping compared to Filiatrault et al. ${ }^{3}$

Sutoyo ${ }^{5}$ extended on the work done by Camelo $^{4}$ by investigating the performance of light-frame timber buildings at high shaking levels. The study used earthquake records from two instrumented light-frame timber buildings. Experimental shake table records from a two and three-story timber frame house were also used. The results showed amplitude dependence for both fundamental frequency and damping estimates. The fundamental frequencies dropped at higher amplitudes and the damping ratios increased for stronger motion. Hysteretic loops were extracted from the earthquake records and from the shake table records. This worked well for the shake table data, however, less so for the earthquake data. Modal parameters of the shake table records were compared to the hysteretic loops and their validity discussed. When a linearized model is used to estimate modal parameters of a timber building experiencing large seismic motions, damping ratios of $12-20 \%$ can be expected. For a timber building displaying linear behavior damping ratios of 5-10\% can be expected. A non-linear model with a custom hysteretic model would use a viscous damping estimate of 5-10\%. This explains the discrepancies seen in damping estimates in Camelo ${ }^{4}$ and Filiatrault et al. ${ }^{3}$

A representative FE model was constructed with the help of various model updating techniques. The model was used as a validation tool to assess the accuracy of extracting the building's hysteretic loops from earthquake records. The hysteretic loops extracted from the updated FE model were shown to be more consistent with current knowledge of timber frame structures than those extracted from the earthquake records. It was concluded that a substantial amount of information about the hysteretic behavior of timber frame buildings could be extracted from earthquake records such as hysteretic curves, structural deformations and amount of energy dissipated. The seismic record database would however substantially benefit from placed strategically multi-axial sensors. The integration of model updating into the investigations was seen as highly useful. 
Return to your MySPIE To Do List at http://myspie.org and approve or disapprove this submission. Your manuscript will not be published without this approval. Please contact author_help@spie.org with any questions or concerns.

Mosalam and Mahin ${ }^{2}$ conducted seismic testing on a typical, near full-scale, asymmetrical, three-story light-frame residential timber building with discontinuities in elevation. The building was tested using a multi-directional shake table without finishes, with finishes, and after retrofitting. The testing confirmed the tendency for the building to twist about the vertical axis and form a weak story mechanism in the lower floor where the tuck-under parking was located. The magnitudes of these tendencies were significantly reduced with retrofit and finishing materials.

Filiatrault et al. ${ }^{6}$ tested a full-scale, two-story, light-frame town house building on two tri-axial shake tables operating in unison. The influence of internal gypsum wallboards and external stucco was investigated. These were shown to improve the seismic response substantially, reducing the first floor drift by $66 \%$. Looking at hysteretic response of the centre of the roof indicated that the wall finishes not only reduced its displacement, but also changed its overall hysteretic characteristics. The timber-only building showed a moderate non-linear response, whereas the other configurations showed an almost linear response. It was concluded that the development of a performance based seismic design method taking into account the effect of wall finishing materials was urgently needed. The building also displayed a weak story mechanism and significant torsional response due the garage opening on the first floor.

Van de Lindt et al. ${ }^{7}$ tested a full-scale, light-frame, seven story timber building on the Japan's E-Defense largest shake table. The objective of the test was to assess the seismic performance of mid-rise light frame timber building with a steel moment resisting frame in the first story. The testing showed that the mid-rise light frame timber building performed better than what was expected from current guidelines and codes.

Ellis and Bougard ${ }^{8}$ dynamically tested a six-story medium-frame timber building at different stages during construction. The purpose of this was to quantify the difference between the stiffness of the bare timber frame of the building, which was used in the dynamic design, and the stiffness of the complete building. Ambient and forced vibration tests were used to measure the characteristics of all the fundamental modes at three key stages of construction: the bare timber frame, the timber frame with staircase, plasterboard walls and ceiling lining, and when the building was completed including the masonry cladding. Results from the experiments showed that the stiffness was increased five-fold for torsion due to the addition of the masonry cladding. The plasterboard and the stairway also had a large effect on the translational stiffness of the building. Results also showed that with increasing seismic amplitudes, the modal frequencies decreased and the damping ratios increased. The authors concluded that an important method for the understanding of the building behavior is using numerical modeling combined with experimental measurements at various stages of construction.

Filiatrault and Folz $\mathrm{z}^{9}$ discussed how timber frame buildings are generally designed as individual components without due consideration for their mutual interaction; unlike the design of steel and concrete buildings, for which capacity design principles have been developed. They reasoned that timber frame building design would therefore benefit greatly from a rational performance based seismic design procedure. The procedure developed used the direct displacement design method as a basis. The procedure did take into account damping due to non-structural components, however, it did not take into account any additional stiffness due to non-structural components.

Pang and Rosowsky ${ }^{10}$ built on the procedure proposed by Filiatrault and Folz ${ }^{9}$ by considering a multi degree of freedom model. Interstory drift limits were determined for three different performance levels: immediate occupancy, life safety and collapse prevention. The procedure, however, is only applicable to timber frame buildings with a relatively symmetric plan and regular shape. An advantage of the procedure is that it avoids the necessity of a non-linear push over analysis as an equivalent viscous damping ratio is not necessary for calculations; however, it does require information about shear wall backbone curves.

Filiatrault et al. ${ }^{1}$ proposed a simple equation for the variation of global viscous damping against building drift to facilitate the use of direct displacement design. To do this, a FE model was developed to model the global loaddisplacement behavior and the variation of the global equivalent damping with displacement amplitude. The model was then validated against the results from shake table testing. It was found that the global equivalent damping ratio against building drift displayed consistent behavior. For building drifts less that $0.4 \%$, it was found that the damping ratio increased linearly to around $18 \%$ of critical damping. For building drifts more than $0.4 \%$, the damping ratio stayed relatively constant around $18 \%$. This, however, did not take into account damping from non-structural elements or structural elements other that the parameter shear walls, and to account for this an additional damping ratio of $2 \%$ was added.

In conclusion, experimental investigations on the seismic performance of light timber frame buildings show conclusive results on the amplitude dependence of both damping and fundamental frequency, significant effect of non-structural elements on stiffness, the tendency for a weak story mechanism to form, and the effect of asymmetry on torsional modes. 
Return to your MySPIE To Do List at http://myspie.org and approve or disapprove this submission. Your manuscript will not be published without this approval. Please contact author_help@spie.org with any questions or concerns.

Design procedures have been developed for light-frame timber buildings, however, they do not take into account the effect of wall finishings on global stiffness and hysteretic performance. Further studies need also to be done on the effect of non-structural elements on the hysteretic performance of buildings. Less research has been performed on medium to heavy timber frame buildings, however, there are some similar seismic characteristic to light-frame timber buildings, such as amplitude dependence of both damping and fundamental frequency and increasing global stiffness due to nonstructural elements. The usefulness of combining numerical modeling with experimental measurements at various stages of construction to deepen the understanding of seismic performance has also been established but needs to be more vigorously pursued.

\subsection{Footfall induced floor vibrations and their monitoring}

Improved mechanical properties of construction materials have enabled engineers to design lighter and more slender structures. In addition to economic factors, this is often driven by the desire to achieve more aesthetically pleasing architectural expression. The current push towards stronger and lighter materials and structural systems is resulting in increasing liveliness of long-span floors in buildings. Modern floors with large spans are lightweight constructions with low stiffness and low natural frequencies, and are therefore more easily excited by dynamic footfall loading. With an increasing number of floors failing in their vibration serviceability ${ }^{11}$, robust methods for the assessment of floor vibration have become essential. Footfall induced loading has proved to be the major source of floor vibration disturbance. Excessive floor vibrations due to walking and similar activities can be considered as probably the most persistent floor serviceability problem encountered by designers.

The difficulty in vibration design is the poor correlation between the outcome of computations at the design stage and the response of the floor constructed accordingly. In addition to the uncertainties inherent in material properties, damping characteristics and boundary conditions, the level of vibrations perceived by individuals, the vibration that is considered objectionable, and the force and frequency of foot drop are all highly subjective and/or prone to large variations ${ }^{12}$.

During walking, a pedestrian produces a dynamic time varying force which has components in all three directions: vertical, horizontal-lateral and horizontal-longitudinal. The vertical component of the force is relevant for floor vibrations and has been experimentally quantified. Andriacchi et al. ${ }^{13}$ measured single step walking forces in all three directions by means of a force plate. Hechler et al. ${ }^{14}$ measured the step frequency of 200 persons passing the entrance hall of an administration building. It was noted that all footfall loading parameters are highly different for different persons but some general conclusions can be drawn.

A reliable statistical description of normal walking frequencies was given by Matsumoto et al. ${ }^{15,16}$, who investigated a sample of 505 persons. They concluded that the frequencies followed a normal distribution with a mean pacing rate of $2.0 \mathrm{~Hz}$ and standard deviation of $0.173 \mathrm{~Hz}$. Leonard ${ }^{17}$ concluded that the normal walking frequency range is $1.7-2.3 \mathrm{~Hz}$, which is in broad agreement with the findings of Matsumoto et al. There are also some proposals as to the typical frequency ranges for different human activities (running, jumping, bouncing, etc.), e.g., Bachmann et al. ${ }^{18}$ defined typical frequency ranges of $1.6-2.4 \mathrm{~Hz}$ for walking, $2.0-3.5 \mathrm{~Hz}$ for running, $1.8-3.4 \mathrm{~Hz}$ for jumping, $1.5-3.0 \mathrm{~Hz}$ for bouncing and $0.4-0.7 \mathrm{~Hz}$ for horizontal body swaying while stationary.

For an open plan office, an upper limit of $2.1 \mathrm{~Hz}$ for walking pace is acceptable. For low height partitioned office spaces and labs, $1.8 \mathrm{~Hz}$ is more appropriate. In the absence of more detailed information, a walking frequency of $2 \mathrm{~Hz}$ is recommended. Being periodic but non-sinusoidal, walking forcing functions have significant higher harmonics in addition to the fundamental one. Frequencies of these are integer multiplies of the fundamental walking frequency (1.5$2.5 \mathrm{~Hz}$ ) and have the potential to excite the fundamental or other vibration resonances ${ }^{12}$. In design and analysis, the inclusion of several loading harmonics and higher structural modes is often necessary.

While floor dynamic testing has relatively rich literature, comprehensive in-service floor vibration studies through longterm monitoring are comparatively less frequently undertaken, indicating the need for more such research. Samarajiva and Choudhuri ${ }^{19}$ monitored structural vibrations in a fitness center area and adjacent computer server room. Aerobic activities were simulated by people spot jogging on the floor. Vibration levels were monitored inside the computer server room, the proposed aerobics area and at a location close to the proposed treadmill area. The vibration levels due to simulated aerobic activities in the computer server room were significantly above the acceptable threshold for the computer equipment room. It was recommended that the floor system be modified to reduce floor vibrations.

Salyards et al. ${ }^{20}$ investigated complaints of disturbing vibration levels from the occupants of a newly constructed academic building. A remote monitoring system was used for floor vibration monitoring. Analysis of the collected data 
Return to your MySPIE To Do List at http://myspie.org and approve or disapprove this submission. Your manuscript will not be published without this approval. Please contact author_help@spie.org with any questions or concerns.

revealed the vibrations were not due to walking but were attributed to several other sources ranging from wind to traffic to mechanical equipment to leg jiggling.

Huston et al. ${ }^{21}$ describe monitoring of floor vibrations in a steel frame research building housing delicate precision instruments that can be adversely affected by even small floor vibrations. The measurements were compared with industry standards and with measurements taken at nearby reinforced concrete buildings. The efforts at reducing the vibrations due to the mechanical systems of the building were also assessed.

\section{THE NELSON MARLBOROUGH INSTITUTE OF TECHNOLOGY TIMBER BUILDING AND ITS INSTRUMENTATION}

\subsection{Structural system}

The three-story NMIT timber building was completed in January 2011. The NMIT building complex has three seismically separate sections: the one-story Media building, one-story Workshop building and three-story Arts building as shown in Fig. 1. The major building of interest is the Arts building (Fig. 2), which is a combination of staff offices and small classrooms. Structurally, the building has non-moment resisting frames for vertical loads. The key innovation is the provision of dual timber post-tensioned shear walls in both directions. The structural design was based on EXPAN technology developed by the University of Canterbury as part of Structural Timber Innovation Company consortium ${ }^{22}$. The laminated veneer lumber (LVL) shear walls are designed to rock from side to side in a major earthquake and have energy dissipating devices between the two panels of each shear wall pair. The lateral deformation is expected to be up to a maximum of $130 \mathrm{~mm}$ and the shear walls will uplift as much as $50 \mathrm{~mm}$. The post-tensioning is provided by four 32 $\mathrm{mm}$ rods tensioned to $340 \mathrm{kN}$ each. There is specialized detailing to allow the freedom of movement and this includes the major lateral load transfer via cylindrical connectors with Teflon spacers and slotted location bolts so that rotation does not induce moment, and U-shaped yielding steel energy dissipaters (Fig. 3). The shear walls link to the frame and lateral load is transferred through the floor diaphragm.

The majority of the floors use a proprietary LVL Potius floor system with concrete topping, while cantilevered parts are reinforced concrete. The main floor beams are double units $750 \mathrm{~mm} \times 89 \mathrm{~mm}$ with a sawn pre-camber and shear

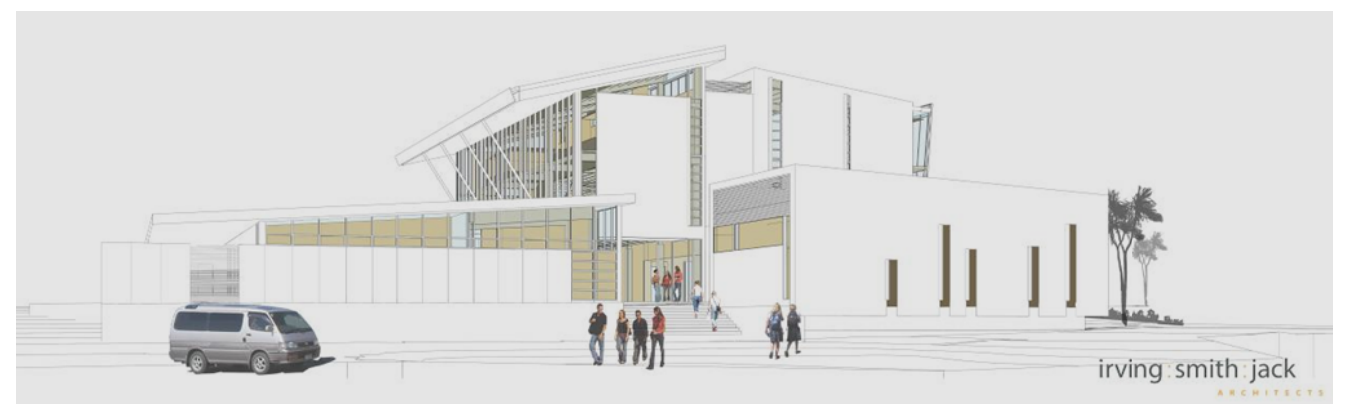

Figure 1. Nelson Marlborough Institute of Technology innovative timber building: Workshop building on the left, Media building on the right, and Arts building at the back (courtesy Irving Smith Jack Architects).

a)

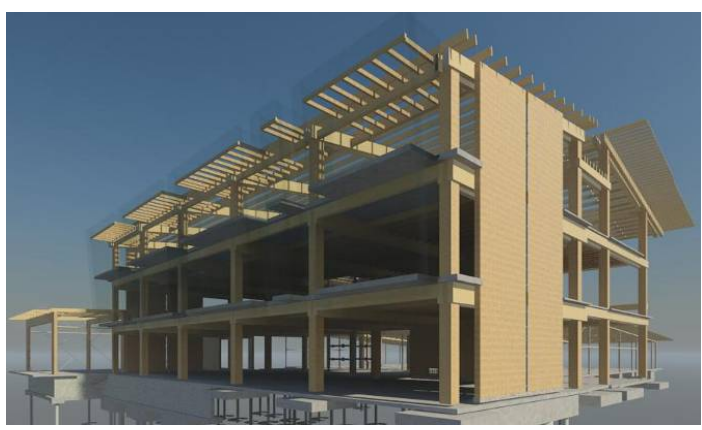

b)

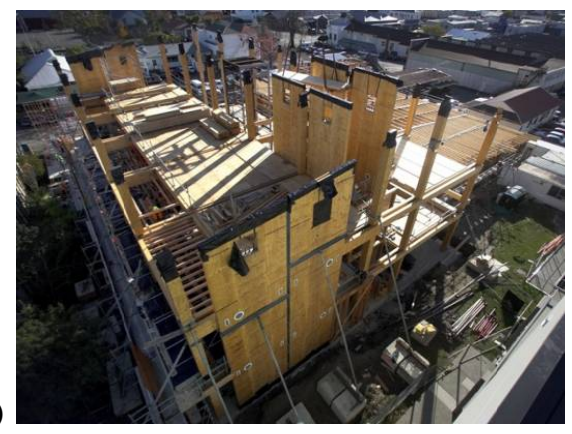

Figure 2. The Arts building: a) structural system with shear walls (courtesy Aurecon), and b) building during construction. 
Return to your MySPIE To Do List at http://myspie.org and approve or disapprove this submission. Your manuscript will not be published without this approval. Please contact author_help@spie.org with any questions or concerns.

a)

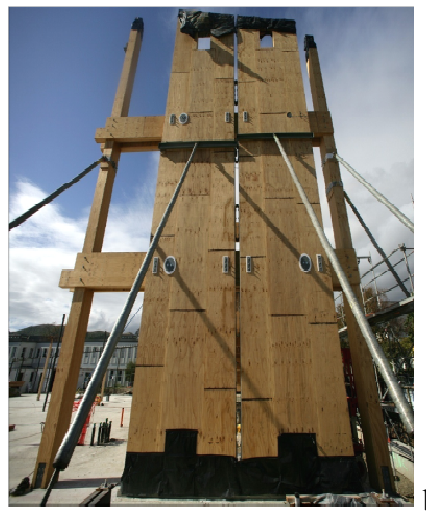

b)

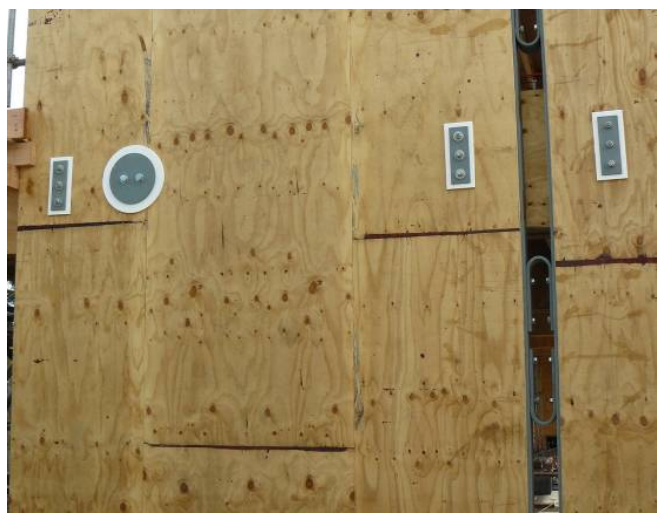

Figure 3. Post-tensioned timber shear wall: a) shear wall during erection, and b) cylindrical shear connectors with

Teflon spacer, slotted location bolts and U-shaped yielding steel energy dissipaters.

connectors to provide composite action with the concrete topping. The concrete topping was cast independently over the secondary cross-beams using a membrane to minimize composite action and shrinkage was allowed to occur before the main beams infill toppings were poured.

\subsection{Instrumentation}

The long-term instrumentation was installed mainly in the Arts building with some sensors also in the Media building. The monitoring system can be conceptually broken into four parts: i) a set of tri-axial accelerometers and an anemometer to capture overall dynamic responses of the building due to seismic and strong winds excitation, ii) instrumentation of shear walls to measure dynamic and long-term responses, iii) strain gauges, LVDTs, and temperature and humidity sensors for measuring long-term deformations of structural timber components, iv) a set of uni-axial, vertical accelerometers measuring footfall induced floor vibrations.

\subsubsection{Instrumentation for monitoring of overall seismic and wind responses}

Figure 4 shows the NMIT Arts building instrumentation installed for the purpose of measuring the overall building response due to seismic and wind excitations. The system was designed and implemented by GNS Science and is fully integrated with GNS Science's broader GeoNet structural monitoring program comprising several buildings and bridges $^{23}$. The typical sensors are three-axial accelerometers distributed within the building to obtain lateral and torsional modal responses. A reference free field accelerometer for measuring input earthquake ground motions is placed in the best available location (shown as accelerometer 10). Several LVDTs measuring shear wall responses are also a part of this system but are described in the next section. A GPS unit is configured to obtain precise timing to about $1 \mathrm{~ms}$ and a central CUSP-ME-16 data logger by Canterbury Seismic Instruments collects the data at $200 \mathrm{~Hz}$ from the distributed

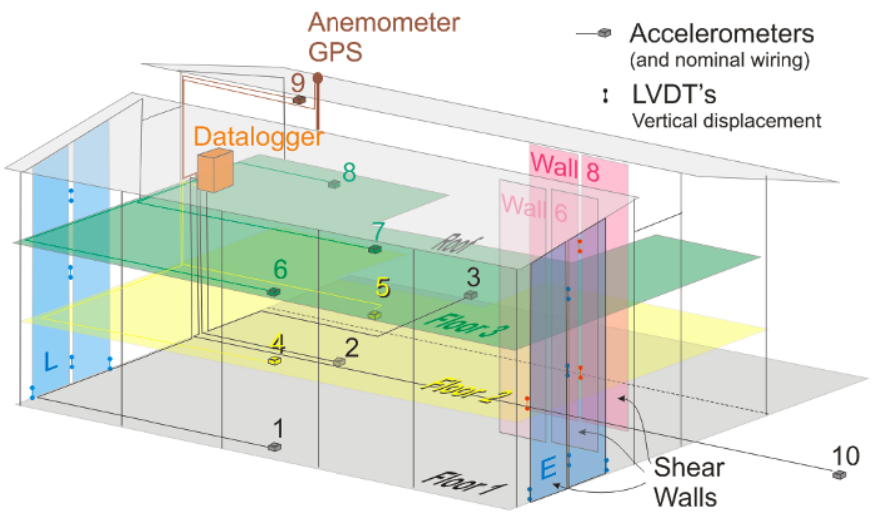

Figure 4. Monitoring system for measuring seismic and wind responses. 
Return to your MySPIE To Do List at http://myspie.org and approve or disapprove this submission. Your manuscript will not be published without this approval. Please contact author_help@spie.org with any questions or concerns.

sensors through Ethernet wiring. The stored data are continuously transmitted to GeoNet data centre through a dedicated IP connection. The system has backup battery power and beyond nominated acceleration trigger levels the data will be stored locally. In this way, key data are retained even if there is an interruption to the power or data network due to a major wind storm or seismic event. The system was designed to be robust, moderate cost, low maintenance and protected against component obsolescence.

\subsubsection{Instrumentation for monitoring of shear wall responses}

Figure 5 shows the instrumentation of one of the shear walls. For the shear walls, both dynamic and long-term responses are of interest. Dynamic instrumentation consists of RDP Group DCTH LVDTs located at the corners of the wall to measure uplift when the wall rocks, and an additional LVDT measuring deformation across a U-shaped passive energy dissipater. For long-term behavior monitoring, a custom modified CCG series annular ring $450 \mathrm{kN}$ load cells from Applied Measurements Ltd were installed prior to the preliminary post tensioning of the wall and the initial load deformation due to full post tensioning was recorded. Steel weights of $50 \mathrm{~mm}$ diameter were hung from a wire attached at the top of the wall to form a reference for measuring long-term wall shortening. These measurements are taken using LVDTs fixed to the wall foundation. Temperature and humidity are recorded in the major spaces around the shear walls

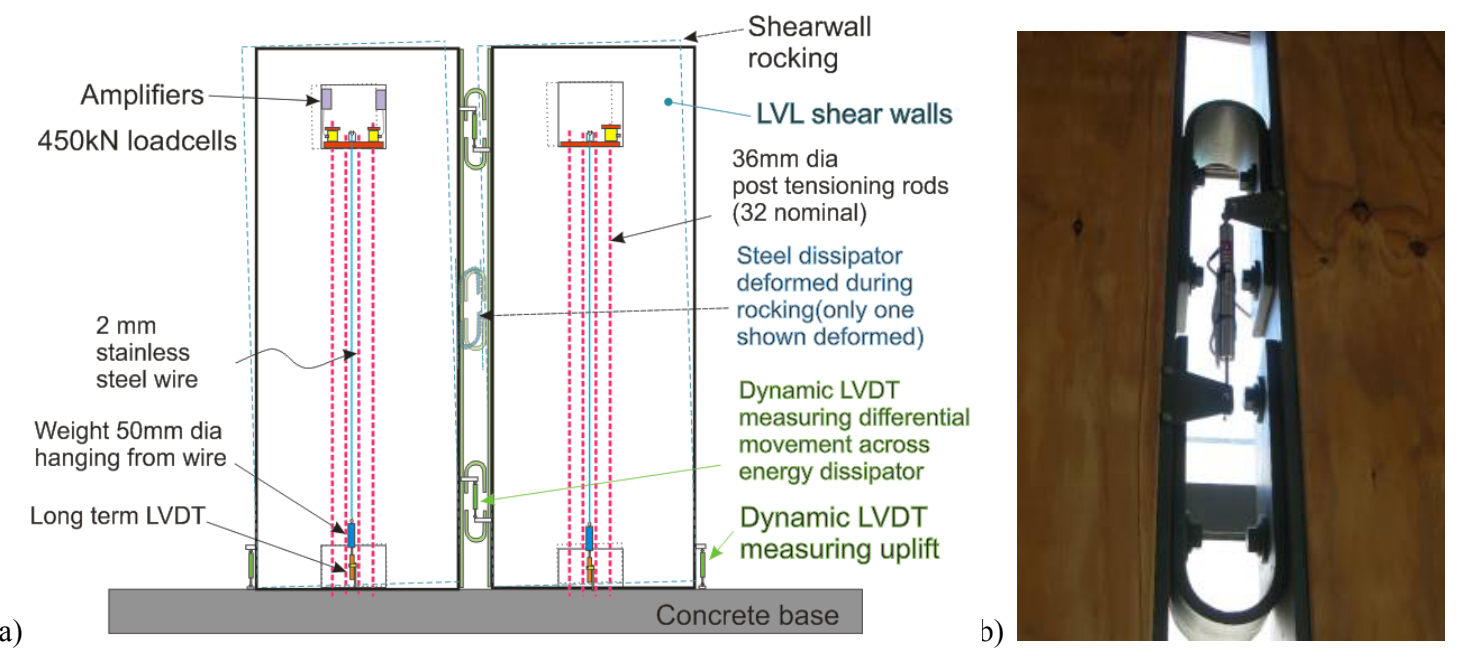

Figure 5. Shear wall instrumentation: a) overall view, and b) LVDT to measure deformation of energy dissipater.

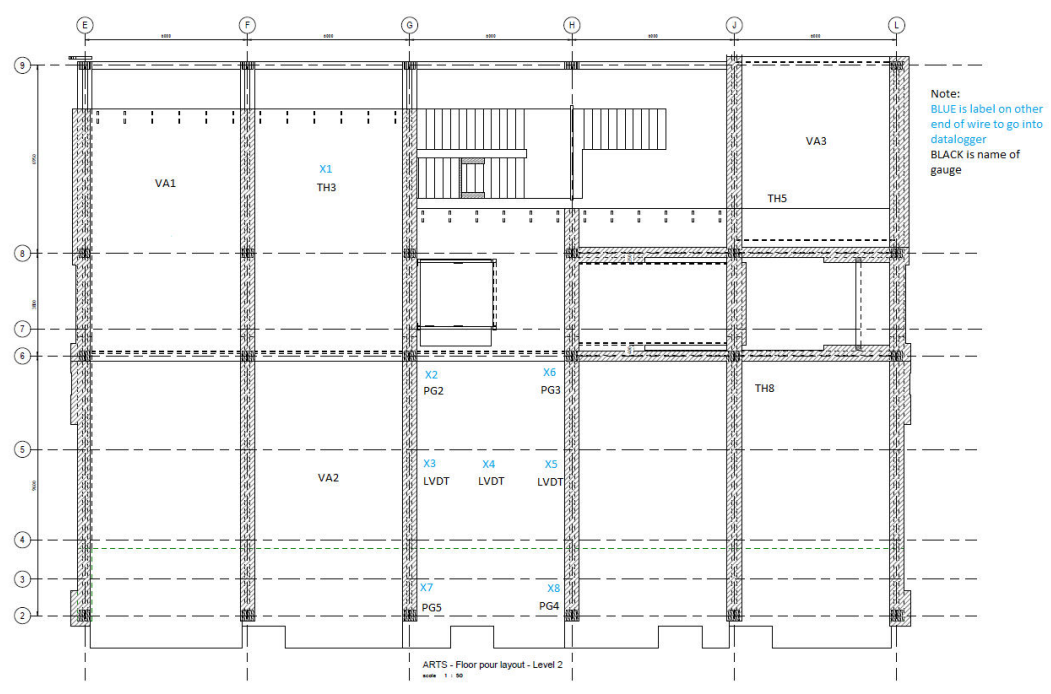

Figure 6. Locations of floor accelerometers (denoted VA1 through VA3). 
Return to your MySPIE To Do List at http://myspie.org and approve or disapprove this submission. Your manuscript will not be published without this approval. Please contact author_help@spie.org with any questions or concerns.

as well as within on exterior shear wall cavity using Vaisala HMP50 sensors. These data will enable a reasonable estimate of the LVL moisture content, known to influence considerably the mechanical properties of timber.

\subsubsection{Instrumentation for monitoring of floor vibrations}

Deciding on an optimal sensor placement is a common problem encountered in many engineering applications and is a critical issue in the design and implementation of an effective structural health monitoring system ${ }^{24}$. Office floors are often irregular in plan, have openings, uncertain boundary conditions and complex structural systems, resulting in complex dynamics. The loading due to their usage may lead to multimodal response that needs to be captured by a limited number of strategically positioned sensors. A great deal of research has been conducted on optimal sensor placement using a variety of placement techniques and criteria. Meo and Zumpano ${ }^{24}$ compared six different optimal sensor placement techniques and concluded that the effective independence-driving point residue (EfI-DPR) method, proposed by Kammer ${ }^{25}$ and Kammer and Tinker ${ }^{26}$, provides an efficient method for optimal sensor placement to identify the vibration characteristics. In this monitoring system design, the technique was augmented by a combinatorial search for the optimal solution ${ }^{27}$. The final layout of three accelerometers, denoted in Fig. 6 as VA1 through VA3, was decided as a trade-off between the optimization results and some practicality and feasibility considerations.

\subsubsection{Instrumentation for monitoring of long-term deformations of structural timber components}

The components of this system are mainly located in the Arts building and their locations are shown in Fig. 7; some additional sensors were also installed in the Media building. Note Fig. 7 also shows long-term shear wall sensors and floor accelerometers, as all these sensors were collected to a National Instruments $533 \mathrm{MHz}$ CRIO-9022 data logger installed by the University of Auckland. Several temperature and humidity sensors were positioned in close proximity to the monitored structural components. The long-term floor sag is monitored with LVDTs using a taut-wire baseline system for the measurement reference ${ }^{28}$. As shown in Fig. 8, a catenary wire is hung over a pulley, in between the $750 \mathrm{~mm}$ deep beams with a $40 \mathrm{~kg}$ mass to maintain constant tension so that temperature compensation is not necessary.

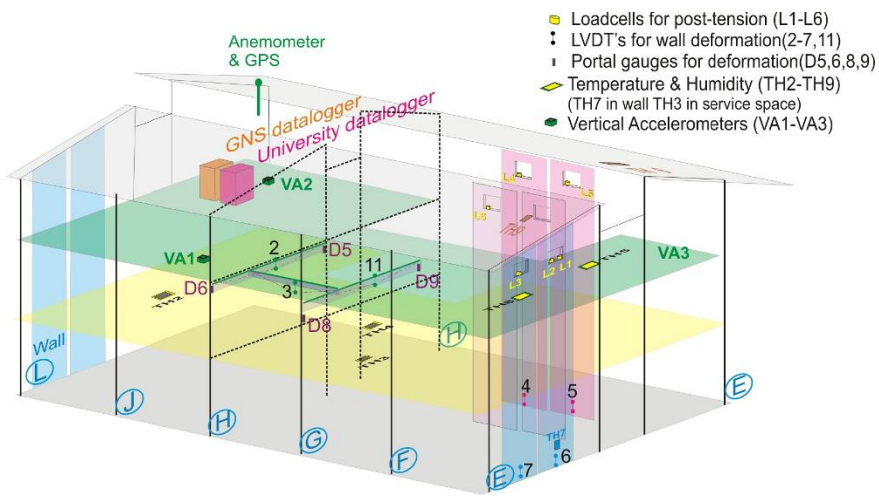

Figure 7. Instrumentation for monitoring of long-term deformations of structural timber components (shear wall sensors and floor accelerometers also shown).

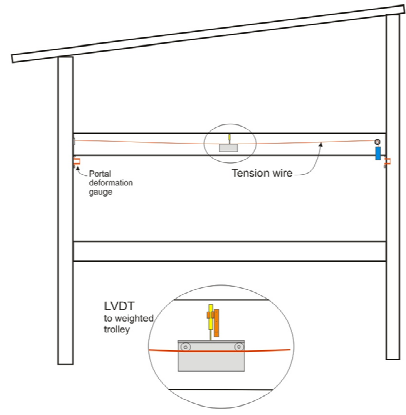

a)

Figure 8. Taut-wire baseline system with an LVDT for
wire tensioning weight, and c) LVDT and trolley.
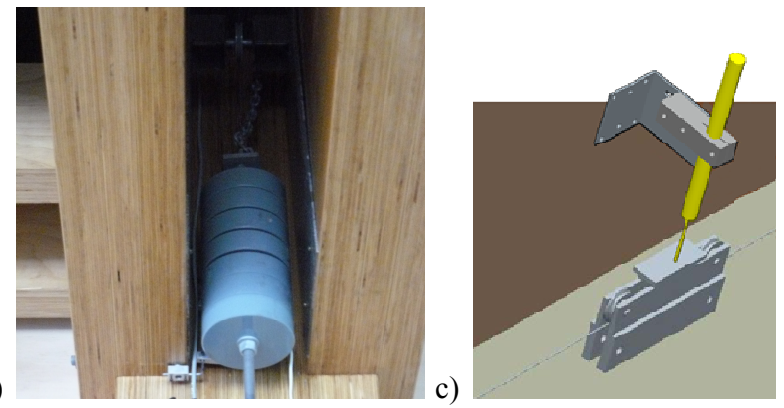
Return to your MySPIE To Do List at http://myspie.org and approve or disapprove this submission. Your manuscript will not be published without this approval. Please contact author_help@spie.org with any questions or concerns.

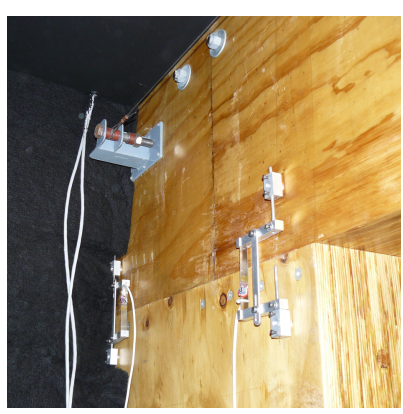

Figure 9. Monitoring knee rotations with "portal” strain gauges.

Also between the beams, a small trolley reduces dynamic wire flutter for the LVDT contact. A similar system without a trolley monitors deformation for the $6 \mathrm{~m}$ span floor system.

The Media building has four simple haunched portal frames that are a modest span. As shown in Fig. 9, the instrumentation uses linear "portal" type strain gauges to determine crushing and joint rotation with a vertical LVDT connected to a baseline wire to monitor deformation. Clearance limits mean that a trolley could not be used and the tip of the LVDT is directly fixed to the wire.

\section{POST TENSION LOSSES AND TIME DEPENDANT DEFORMATIONS}

\subsection{Data validation, variation and environmental factors}

Most of the deformation instrumentation as outlined above is recorded based on averaging 100 readings at 10 minute intervals. For two load cells and one floor beam the data is logged at $100 \mathrm{~Hz}$. The data was compared and the 100 readings for the moving average was validated as representative. The electrical noise sensitivity and the system error was calculated as $\pm 0.05 \mathrm{~mm}$ for the LVDTs, $\pm 0.5 \mathrm{kN}$ for the load cells, $\pm 0.2 \%$ for relative humidity and $\pm 0.15^{\circ} \mathrm{C}$ for temperature. This is small relative to the daily variations.

The wall compressive deformation measurements and the thermal extension of the post tensioning steel are temperature sensitive. Temperature variations within the wall cavity are more stable, over a sample week exterior temperature varied by $13^{\circ} \mathrm{C}$ but inside the wall by just $3.5^{\circ} \mathrm{C}$. A temperature profile was measured within the wall from $21.2^{\circ} \mathrm{C}$ to $22.2^{\circ} \mathrm{C}$ while the adjacent ambient temperature was $23^{\circ} \mathrm{C}$, the changes were clear at every floor level. Humidity has a major impact on the timber moisture content which causes shrinking and swelling. Daily variations of humidity will therefore change the wall length and post-tension stress.

Figure 10 shows the analysed load change values due to temperature and humidity compared to the measured load changes over a month. Note that the load scale for temperature is 20 times the load scale for humidity. The temperature effect is much more significant and correlates very closely with weekly prediction. The effect of humidity is about $5 \%$ of the temperature effect and has a slightly lower direct correlation. Over the month, the temperature and humidity effects result in a zero change. The trend for the actual load is a loss of $3 \mathrm{kN}$.

While the variations are significant and largely predictable, the trends over months of time are still clear prior to detailed data correction.

\subsection{Wall deformations and post-tension losses \\ Wall deformations}

In June 2010, a post-tensioning load of $\sim 348 \mathrm{kN}$ was applied; the immediate elastic deformation was approximately $2.5 \mathrm{~mm}$. On site manual deformation measurements were not precise. The next reliable data was taken in April 2011. From April 2011 to July 2011, the deformation trend of the shear walls was $0.2 \mathrm{~mm}$ to $0.6 \mathrm{~mm}$. One LVDT in the shear wall deformed considerably more at $1.5 \mathrm{~mm}$. The shear wall deformations are subject to daily measurement variation which is well correlated to the interior temperature.

Table 1 shows the post tension losses with time. The initial post tensioning target was $348 \mathrm{kN}$ and was achieved within 3 $\mathrm{kN}$ but the load then varied as adjacent rods were tensioned, load cell LC4 dropped by $11.7 \mathrm{kN} 10$ minutes after 
Return to your MySPIE To Do List at http://myspie.org and approve or disapprove this submission. Your manuscript will not be published without this approval. Please contact author_help@spie.org with any questions or concerns.

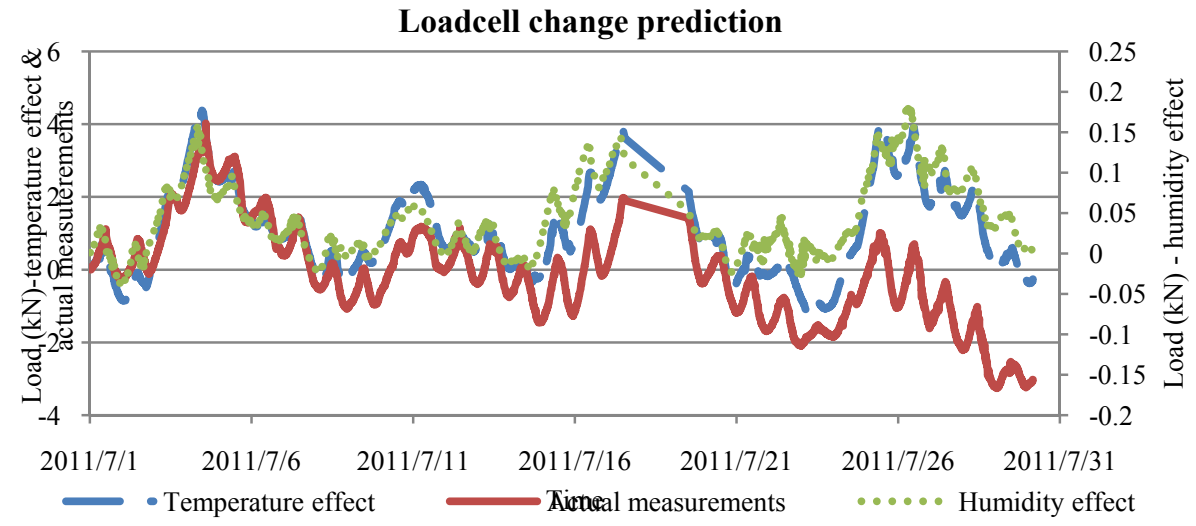

Figure 10. Load prediction from temperature and humidity variation compared with measured post-tension.

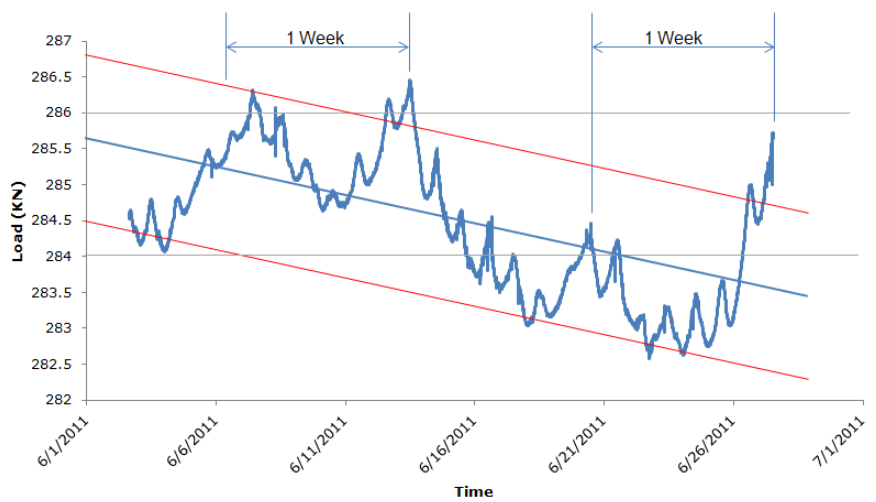

Figure 11. Post tension load trend for load cell LC6 over a month showing daily and weekly variation.

tensioning. Loads values are given after 1 day then from April 2010, when the monitoring system was fully functional, May, July, and the most recent values from October 2011 after 16 months. The overall load changes are expressed as loss percentage of the initial load after all rods were tensioned and jacking was complete; additionally losses as a percentage after the first day are noted.

A direct comparison of deformations with similar lead up temperatures and the same temperature at the time of reading over 6 months in May 2011 and again in October 2011 gave the results shown in Table 2. This was selected for similar temperature surrounding all instrumented shear walls. Wall 6 is on the North side and may be subject to more thermal and humidity changes in the Southern hemisphere. It had the greatest deformation and this has corresponded to the greatest post-tension losses.

Post-tension loses

As outlined in Table 2, loads changed reasonably consistently with the deformation change. The values for one load cell over a month are shown in Figure 11 which highlights the daily and weekly variations. (The heating was turned off for the weekend). The trend of the load changes is shown by plotting the difference from the value at 1 April in Figure 12. 
Return to your MySPIE To Do List at http://myspie.org and approve or disapprove this submission. Your manuscript will not be published without this approval. Please contact author_help@spie.org with any questions or concerns.

\begin{tabular}{|c|c|c|c|c|c|c|c|c|c|}
\hline Time & $\begin{array}{l}\text { June } \\
2010 \\
\end{array}$ & & $\begin{array}{c}\text { April } \\
2011 \\
\end{array}$ & May & July & October & Losses & $\begin{array}{c}\text { Losse } \\
\text { s }\end{array}$ & Losses \\
\hline & $\begin{array}{c}\text { Initial } \\
\mathbf{k N}\end{array}$ & 1 day & $\begin{array}{c}\mathbf{1 0} \\
\text { Months } \\
\mathbf{k N} \\
\end{array}$ & $\begin{array}{c}11 \\
\text { Months } \\
\mathbf{k N}\end{array}$ & $\begin{array}{c}\mathbf{1 3} \\
\text { Months } \\
\mathbf{k N} \\
\end{array}$ & $\begin{array}{c}\mathbf{1 6} \\
\text { Months } \\
\mathbf{k N} \\
\end{array}$ & $\mathbf{k N}$ & $\begin{array}{c}\% \\
\text { Initial }\end{array}$ & $\begin{array}{c}\% \\
\text { from } \\
\text { day } 1 \\
\end{array}$ \\
\hline LC6 & 341 & 334.4 & 293 & 287 & 277 & 272.7 & 68.3 & 20.0 & 18.4 \\
\hline LC5 & 347.9 & 344.7 & 290 & 287 & 282 & 276.3 & 71.9 & 20.6 & 19.8 \\
\hline LC4 & 350.5 & 337.5 & 320 & 315 & 306 & 301.8 & 48.7 & 13.9 & 10.5 \\
\hline LC3 & 348 & 347.6 & 294 & 291 & 290 & 282.4 & 65.6 & 18.8 & 18.8 \\
\hline
\end{tabular}

Table 2. Changes in compressive deformation and post tension May to October 2011.

\begin{tabular}{|l|c|c|c|c|}
\hline Shear wall & $\begin{array}{c}\text { Deformation } \\
\text { sensor }\end{array}$ & $\begin{array}{l}\text { Compressive } \\
\text { deformation } \\
\text { change } \\
\text { (mm) }\end{array}$ & Load sensor & $\begin{array}{l}\text { Post-tension } \\
\text { loss (kN) }\end{array}$ \\
\hline Wall 6 & LVDT 4 & 1.36 & LC6 & 14.5 \\
\hline Wall 8 & LVDT 5 & 0.77 & LC4 & 13.3 \\
\hline Wall 8 & & & LC5 & 11.2 \\
\hline Wall L & LVDT 6 & 0.41 & & \\
\hline Wall L & LVDT 7 & 0.53 & LC3 & 8.5 \\
\hline
\end{tabular}

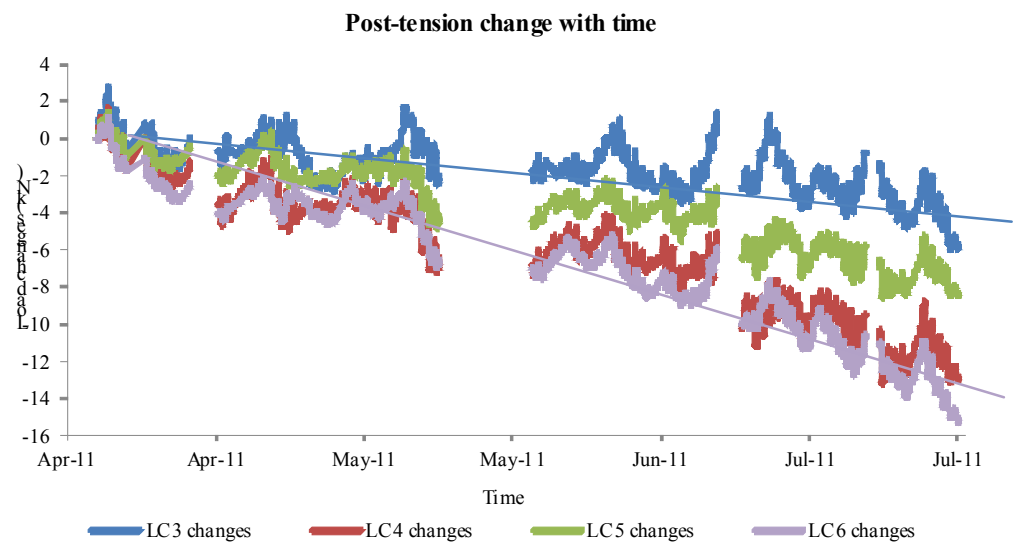

Figure 12. Post-tension load changes over 4 months showing range of trends.

Figure 13 plots the long term deformation from April 2011 to March 2012. It shows the major composite beams have a larger creep deflection compared to the secondary non-composite Potius floor beam. Over almost a year, the composite beams had a deflection of 3 to $4 \mathrm{~mm}$ over a $9.6 \mathrm{~m}$ span and the non-composite beam had $1 \mathrm{~mm}$ over a $5.5 \mathrm{~m}$ clear span. This is equivalent to $30 \%$ and $15 \%$ of their respective theoretical elastic deflections due to gravity load only. The overall trend is increasing in downward deformation, the deformation variation synchronized closely with the humidity variation.

Figure 14 is a plot of typical daily variations which was as much as $1.0 \mathrm{~mm}$ in July; the weekly pattern is also visible with significant changes at weekends. Deflection variation is predominantly due to environmental changes with some possible influence from live load changes. This figure shows that the composite beams have larger variation compared to the non-composite Potius secondary beams, because they respond more to the environmental factors. The environmental factors are similar for the two major beams, but the live load situation is different with two different rooms above them. 
Return to your MySPIE To Do List at http://myspie.org and approve or disapprove this submission. Your manuscript will not be published without this approval. Please contact author_help@spie.org with any questions or concerns.

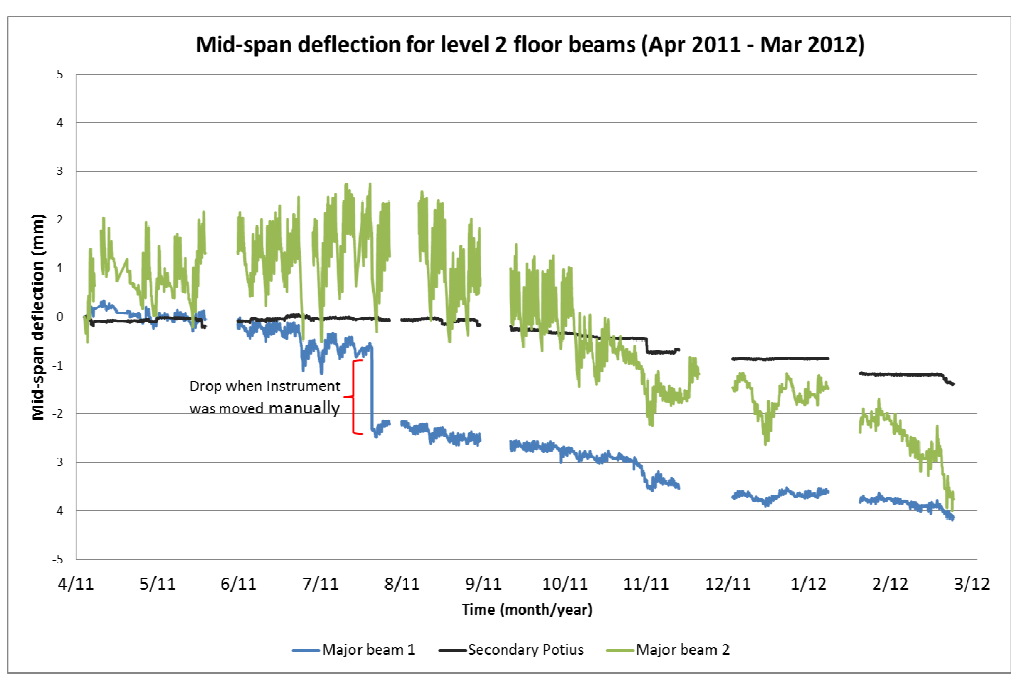

Figure 13. Long term deflection changes since April 2011.

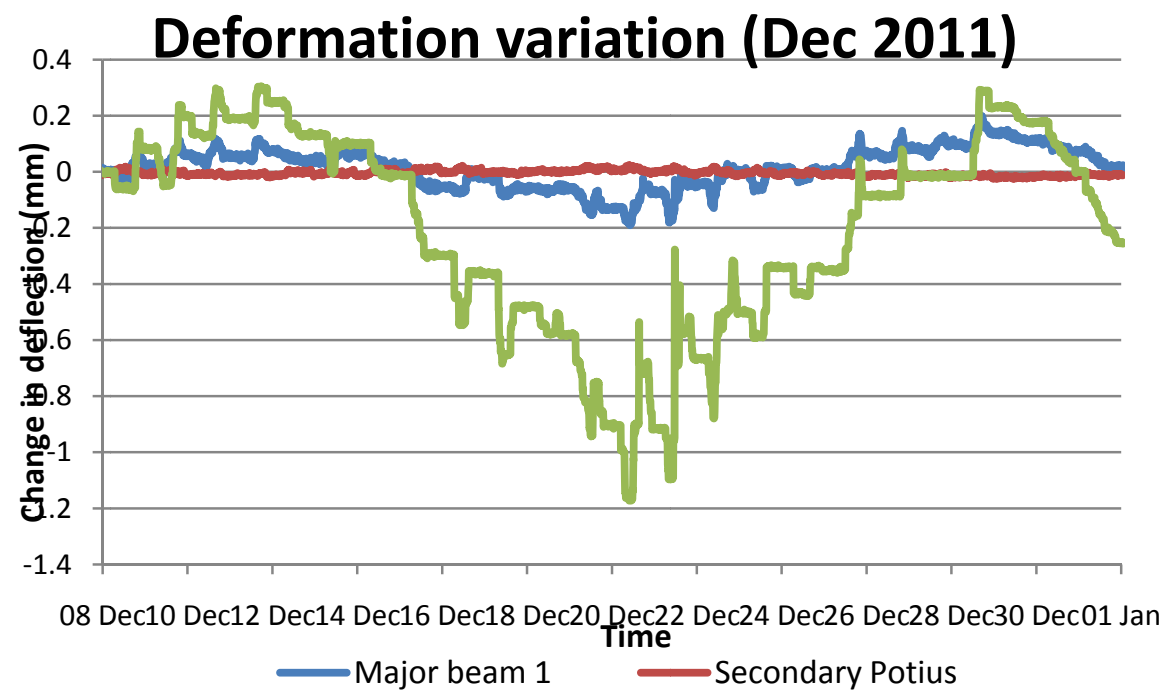

Figure 14. Daily and weekly variation of floor deformation - Dec 2011.

\subsection{Deflection of composite beam vs. non-composite beam}

The timber-concrete composite beams theoretically have larger deflection variations than non-composite beams and this was confirmed by what we observed. The different physical properties of timber and concrete cause different responses in the two materials when subjected to environmental changes. The concrete has a constant distribution of temperature whereas for timber it is variable depending on the distance to the edge of the timber beam. The concrete also has a smaller delay time compared with timber; and the maximum temperature in concrete is higher than timber. The comparative concrete and timber response to humidity is similar to the temperature response; the concrete has a constant distribution, small delay time and high peak humidity.

\section{ANALYSIS OF FLOOR VIBRATION MONITORING DATA}

\subsection{Assessment procedure}

Procedures for evaluation of the effect of vibrations on humans are laid down in documents such as ISO2631$1: 1997(\mathrm{E})^{29}$, ISO10137:2007(E) ${ }^{30}$ and SCI Publication P354 ${ }^{31}$, the relevant approaches being those to asses vibration levels for human perception criteria. In the case of measurements of vibration of a supporting surface for a standing 
Return to your MySPIE To Do List at http://myspie.org and approve or disapprove this submission. Your manuscript will not be published without this approval. Please contact author_help@spie.org with any questions or concerns.

person, ISO2631-1:1997(E ${ }^{29}$ requires raw measured acceleration to be frequency weighted to account for the variable sensitivity of humans to vibrations. Frequency weighting $W_{k}$, a complex function of frequency whose magnitude is shown in Fig. 15, is to be applied to vertical vibrations producing weighted acceleration $a_{w}(t)$. Vibration levels for comparison with acceptable limits are to be calculated using frequency weighted data. It can be seen from Fig. 15 that vibrations in the range of frequencies between $0.7 \mathrm{~Hz}$ and $13 \mathrm{~Hz}$ would be perceived particularly strongly.

The quantity to be used to characterize an average level of vibration is the root mean square $(R M S)$ of weighted accelerations. To take into account the often-encountered spikiness of response, the $R M S$ value for the worst 1 second of weighted acceleration can be used which is calculated as:

$$
R M S_{w, 1 s}=\max _{\text {all } t} \sqrt{\frac{1}{1 s} \int_{t}^{t+1 s} a_{w}^{2}(t) d t}
$$

The $R M S_{w, 1 s}$ value for the worst 1 second of vibrations is used to calculate the response factor ${ }^{30}$ :

$$
R=\frac{R M S_{w, 1 s}}{0.005 m / s^{2}}
$$

Comparison of the response factors with their corresponding thresholds can serve as a way of assessing vibration serviceability, despite the fact that available advice on threshold values varies widely in the available literature ${ }^{31}$.

\subsection{Floor modeling and preliminary monitoring data analysis}

The floor was modeled using the FE software ABACUS. The LVL beams were modeled using beam elements and concrete topping using shell elements. Columns of the stories above and below were also included in the model to take into account their influence on floor vibrations. Young's modulus and density were $10.7 \mathrm{GPa}$ and $570 \mathrm{~kg} / \mathrm{m}^{3}$ for timber and $30 \mathrm{GPa}$ and $2,400 \mathrm{~kg} / \mathrm{m}^{3}$ for concrete, respectively.

Modal analysis revealed that there were 22 modes below $12.5 \mathrm{~Hz}$. These are in the range that could be excited by footfall harmonics and also in the range of elevated human perception (see Fig. 15). Figure 16 shows several of the lowest frequency modes. It can be seen that due to irregularities and openings in the floor they are localized in either the lower part of floor, where several small classrooms are located, or in both upper corners used for offices and galleries.

Figure 16a shows, as an example of typical trends, peak weighted accelerations for 30 minute intervals for a single day, Monday, May $3^{\text {rd }}, 2011$. A clear pattern can be seen where any appreciable activities occur, as expected, only between $7.00 \mathrm{am}$ and $8.30 \mathrm{pm}$. The peak weighted acceleration values are typically less than $1.5 \mathrm{~m} / \mathrm{s}^{2}$, though at times they are exceeded up to nearly $2.0 \mathrm{~m} / \mathrm{s}^{2}$. Figure $16 \mathrm{~b}$ shows peak daily weighted accelerations for a period of nearly three weeks starting Saturday, May $1^{\text {st }}, 2011$. Another expected pattern is confirmed where a much larger level of response, up to approximately $2.0 \mathrm{~m} / \mathrm{s}^{2}$, occurs during weekdays, with much smaller vibrations during weekends. (The increased levels of vibration starting on Friday, May $13^{\text {th }}, 2011$ are probably due to some construction works being carried out.) Figure

17a shows $R M S$ values for the worst 1 second of weighted acceleration (Eq. (1)) extracted from 30 minute long intervals

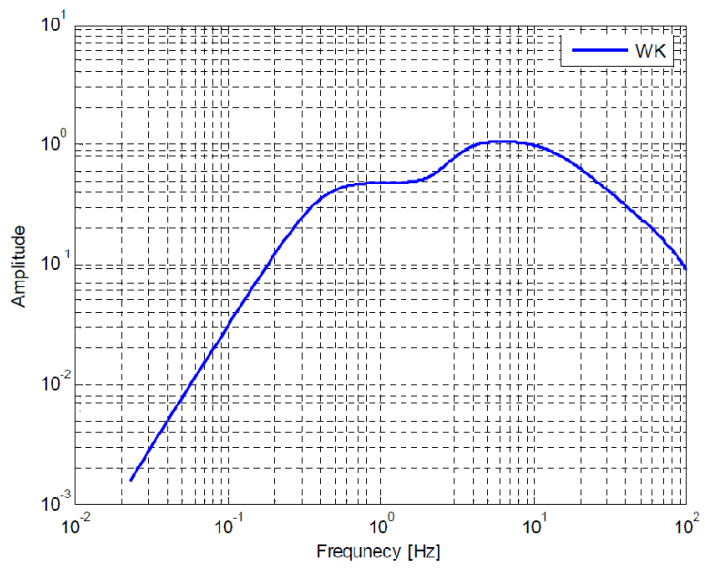

Figure 15. Magnitude of frequency weighting function $W_{k}$ for vertical vibrations. 
Return to your MySPIE To Do List at http://myspie.org and approve or disapprove this submission. Your manuscript will not be published without this approval. Please contact author_help@spie.org with any questions or concerns.

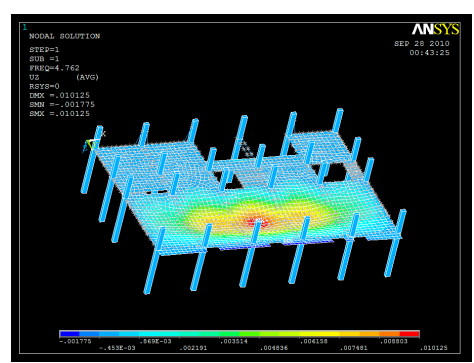

$4.76 \mathrm{~Hz}$

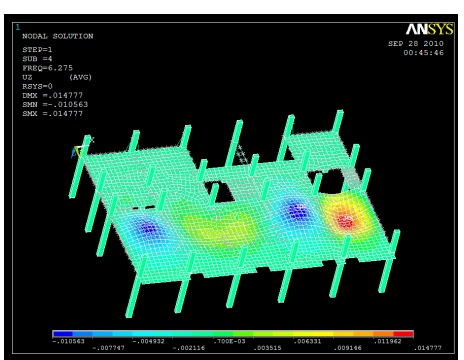

$6.28 \mathrm{~Hz}$

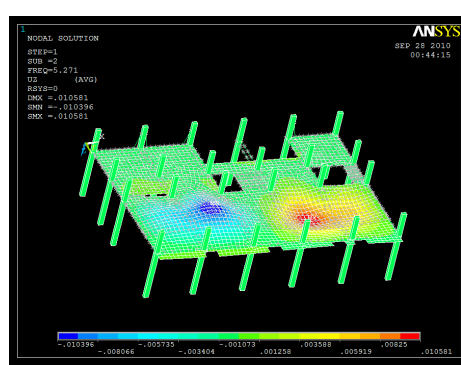

$5.27 \mathrm{~Hz}$

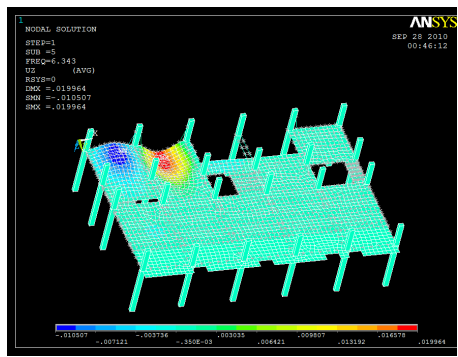

$6.34 \mathrm{~Hz}$

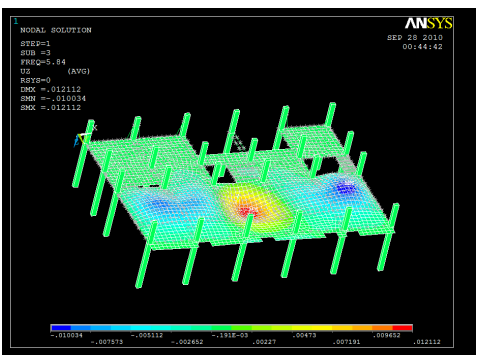

$5.84 \mathrm{~Hz}$

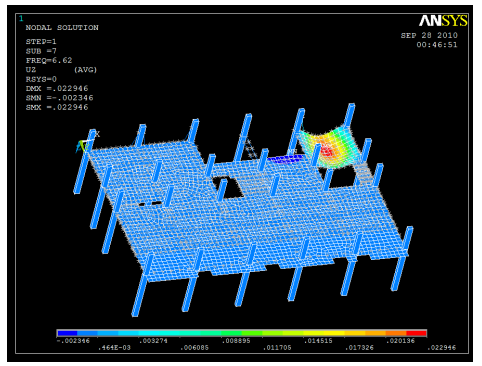

$6.62 \mathrm{~Hz}$

Figure 16. Selected lowest modes of floor vibrations by FEM analysis.

on Monday, May $3^{\text {rd }}, 2011$. The maximum values of up to approximately $0.2 \mathrm{~m} / \mathrm{s}^{2}$ occur around mid-day. Figure $17 \mathrm{~b}$ shows the corresponding response factors (Eq. (2)) reaching maximum values of up to nearly 40 .

\section{AMBIENT, FORCE DYNAMIC TESTING AND SEISMIC MONITORING DATA ANALYSIS}

\subsection{Ambient and forced dynamic testing program and methodology}

A series of dynamic tests were carried out at six constructions stages in order to observe the changes of stiffness in the building due to structural and non-structural components. Uniaxial Honeywell Q-Flex QA-750 accelerometers were used to measure accelerations for both the ambient vibration testing and the forced vibration testing and two APS Dynamics Model 400 ELECTRO-SEIS long stroke shakers were used to excite the building during the forced vibration testing. The shakers were capable of a peak $445 \mathrm{~N}$ lateral load in the frequency range from $1 \mathrm{~Hz}$ to $12 \mathrm{~Hz}$. During forced testing, the shakers were placed on the second floor where several modes of interest could be strongly excited simultaneously. Generally, several accelerometer setups were used with reference accelerometer(s) in the same location(s), and mode shapes "glued" together. The accelerometers were placed on the first and second floor but none on the roof. During ambient testing, 60 minute long uninterrupted records were taken, sampled at $100 \mathrm{~Hz}$. Forced testing used either 10 minute long frequency sweeps in the range from $1 \mathrm{~Hz}$ to $8 \mathrm{~Hz}$ and from $8 \mathrm{~Hz}$ to $15 \mathrm{~Hz}$, or broadband random excitation sampled at $500 \mathrm{~Hz}$. Ambient testing was performed for all six stages and forced testing for the last stage. Unfortunately, only tests for three of the stages yielded reliable results. Table 3 shows the three stages which gave reliable results.

For seismic monitoring results 10 data sets were obtained for earthquakes over M5.0 on the Richter scale, but with epicenters far away from the structure. Several of the records were from the February 2011 Christchurch earthquake main shock as well as aftershocks but due to the distance from the epicenters had low peak ground accelerations between $0.23 \mathrm{mg}$ and $3.35 \mathrm{mg}$. 
Return to your MySPIE To Do List at http://myspie.org and approve or disapprove this submission. Your manuscript will not be published without this approval. Please contact author_help@spie.org with any questions or concerns.

a)

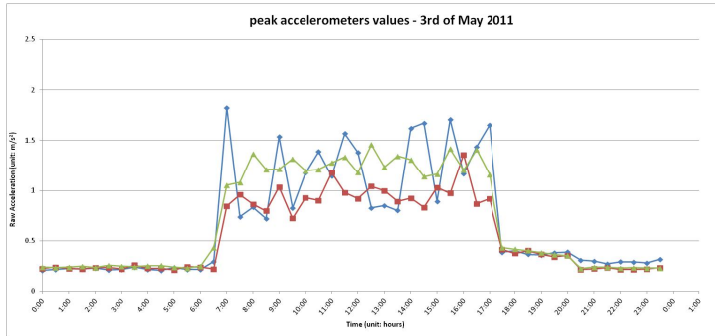

Figure 16. Peak weighted floor accelerations: a) for a single day using 30 minute intervals, and b) maximum daily values for several days.

a)

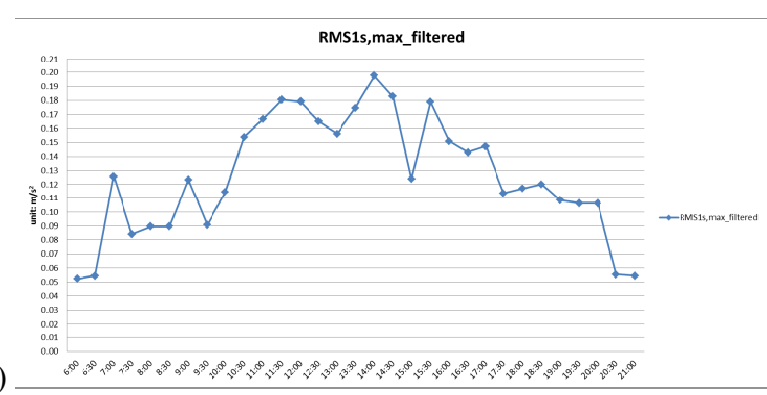

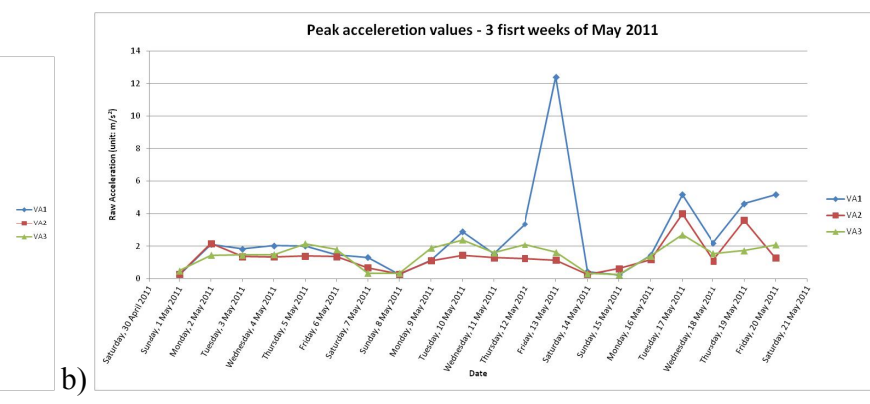

b)

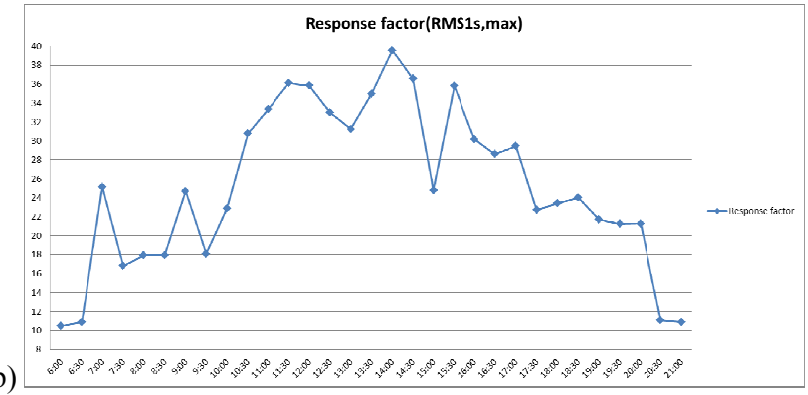

Figure 17. a) $R M S$ values for the worst 1 second of weighted acceleration for a single day using 30 minute long intervals, and b) corresponding response factors.

\subsection{System identification results and discussion}

Experimental data analysis aimed at identification of natural frequencies, damping ratios and mode shapes. Measurements were analyzed using several system identification techniques, including peak picking ${ }^{32}$, enhanced frequency domain decomposition ${ }^{33}$, and data and covariance-driven, output-only and input-output stochastic subspace identification $^{34}$ with stability diagrams. The use of several techniques enhanced the confidence in the modal identification results as only those modes that showed consistency across the various techniques were retained, thus avoiding spurious results often encountered in similar exercises.

Table 4 summarizes the results of system identification providing the natural frequencies and damping ratios identified in the different construction stages and tests. Note that several tests did not yield all the modes and/or their modal characteristics with high enough confidence, and hence those were omitted from the summary. Overall, all the natural frequencies identified in Stage 3 by the different tests agree very well, except for Mode 3 where seismic monitoring yielded a noticeably lower frequency. Examining the changes in frequencies of Mode 1 and 2 as the construction progressed, it can be clearly seen that the addition of concrete floor topping (and the resulting diaphragm action), addition of the roof and shear wall post-tensioning increased the system stiffness markedly, such that the corresponding natural frequencies increased by $123 \%$ and $18 \%$, respectively. Examination of the corresponding mode shapes indicated that the timber frames, previously allowed to move fairly independently, now moved in unison. On the other hand, the changes between Stages 2 and 3 were much less dramatic for Mode 1, increasing the frequency by 19\%, and similar to the previous change for Mode 2, an increase by $24 \%$. It can be thus concluded that cladding had less effect on Mode 1 than the floor completion, roof addition and post-tensioning, but similar on Mode 2. Damping ratios identified for the complete building (Stage 3) were between 1.6\% and 2.4\% for forced vibration testing. Comparison of the results from seismic monitoring shows that natural frequencies are similar, except the aforementioned larger difference for Mode 3. No strong trend is however observed with some frequencies being smaller (Mode 1, 3 and 4) and one larger (Mode 2). On the other hand, damping ratios from seismic monitoring vary between $3.5 \%$ and $4.5 \%$ and are clearly larger than those from forced testing. This is expected as damping normally increases with the amplitude of vibration. 
Return to your MySPIE To Do List at http://myspie.org and approve or disapprove this submission. Your manuscript will not be published without this approval. Please contact author_help@spie.org with any questions or concerns.

Table 3. Construction stages and types of dynamic testing performed.

\begin{tabular}{|c|l|l|}
\hline Stage & \multicolumn{1}{|c|}{ Construction progress } & Type of test performed \\
\hline Stage 1 & $\begin{array}{l}\text { Completed frames, partial concrete floor on first story (no diaphragm } \\
\text { action) }\end{array}$ & Ambient \\
\hline Stage 2 & $\begin{array}{l}\text { As above + completed concrete floors (diaphragm action), roofing, } \\
\text { elevator shaft, shears walls post-tensioned, some external cladding }\end{array}$ & Ambient \\
\hline Stage 3 & $\begin{array}{l}\text { As above + completed external cladding, most of internal cladding, } \\
\text { staircase installed }\end{array}$ & Ambient and forced \\
\hline
\end{tabular}

Table 4. Summary of dynamic test results (natural frequencies and damping ratios).

\begin{tabular}{|c|c|c|}
\hline Stage & Frequency & Damping \\
\hline Stage 1 & $\begin{array}{l}\text { Mode } 1: 1.3 \mathrm{~Hz}^{*} \\
\text { Mode 2: } 2.8 \mathrm{~Hz}^{*}\end{array}$ & $\begin{array}{l}\text { Mode 1: - } \\
\text { Mode 2: - }\end{array}$ \\
\hline Stage 2 & $\begin{array}{l}\text { Mode } 1: 2.9 \mathrm{~Hz}^{*} \\
\text { Mode } 2: 3.3 \mathrm{~Hz}^{*}\end{array}$ & $\begin{array}{l}\text { Mode 1: - } \\
\text { Mode 2: - }\end{array}$ \\
\hline Stage 3 & $\begin{array}{l}\text { Mode 1: } 3.45 \mathrm{~Hz}^{*}, 3.52 \mathrm{~Hz}^{\dagger}, 3.23 \mathrm{~Hz}^{\star} \\
\text { Mode 2: } 4.10 \mathrm{~Hz}^{*}, 4.07 \mathrm{~Hz}^{\dagger}, 4.28 \mathrm{~Hz}^{\star} \\
\text { Mode } 3:-^{*},\end{array}$ & $\begin{array}{l}\text { Mode } 1:-^{*}, 1.6 \%^{\dagger}, 3.4 \%^{\star} \\
\text { Mode } 2:-^{*}, 2.4 \%^{\dagger}, 3.5 \% \%^{*} \\
\text { Mode } 3:-^{*},-^{\dagger}, \quad 4.9 \%^{*} \\
\text { Mode } 4:-^{*}, 1.8 \%^{\dagger}, 3.6 \%^{*}\end{array}$ \\
\hline
\end{tabular}

"Ambient testing, ${ }^{\dagger}$ Forced testing, ${ }^{*}$ Seismic monitoring

Table 5. Comparison between experimental and FE results before and after updating.

\begin{tabular}{|l|l|l|l|l|l|l|l|}
\hline Mode & $\begin{array}{l}\text { Experimental } \\
\text { frequency } \\
\text { (Hz) }\end{array}$ & $\begin{array}{l}\text { Initial FE } \\
\text { frequency } \\
\text { (Hz) }\end{array}$ & $\begin{array}{l}\text { Initial } \\
\text { relative } \\
\text { error (\%) }\end{array}$ & $\begin{array}{l}\text { Final FE } \\
\text { frequency } \\
\text { (Hz) }\end{array}$ & $\begin{array}{l}\text { Final } \\
\text { relative } \\
\text { error (\%) }\end{array}$ & $\begin{array}{l}\text { Initial } \\
\text { MAC } \\
(\%)\end{array}$ & $\begin{array}{l}\text { Final } \\
\text { MAC } \\
\text { (\%) }\end{array}$ \\
\hline Mode 1 & 3.52 & 3.71 & 5.4 & 3.68 & 4.6 & 78 & 78 \\
\hline Mode 2 & 4.07 & 4.43 & 9.1 & 4.14 & 1.8 & 25 & 54 \\
\hline Mode 3 & 6.96 & 6.48 & -6.9 & 6.67 & -4.2 & 72 & 71 \\
\hline Mode 4 & 7.42 & 6.80 & -8.3 & 7.51 & 1.3 & 32 & 79 \\
\hline $\begin{array}{l}\text { Mean } \\
\text { absolute } \\
\text { value }\end{array}$ & & & 7.4 & & 3.0 & 52 & 71 \\
\hline
\end{tabular}

\subsection{Finite element modeling and updating}

A detailed FE model of the building was constructed and later updated using the modal frequencies and mode shapes from the forced vibration testing. The model used a mixture of frame, spring and shell elements, with member dimensions and sizes taken from building construction plans. Model updating was conducted using the software FEMtools. FEMtools uses the sensitivity based updating method ${ }^{35}$. The procedure is iterative: changes to model parameters are applied until the modal properties of the model agree with the experimental ones within acceptable tolerance. The response values used for updating were picked by evaluating the correlation between the experimental 
Return to your MySPIE To Do List at http://myspie.org and approve or disapprove this submission. Your manuscript will not be published without this approval. Please contact author_help@spie.org with any questions or concerns.

modes and the initial FE model modes. Only Mode 1 and Mode 3 correlated well and their frequency and mode shapes (in the form of modal assurance criteria ${ }^{35}$ ) were used as the response values during updating. The total updating error was assumed to be the sum of the relative absolute value errors between the experimental and model frequencies and modal assurance criteria. Due to the small number of response values, only a small number of parameters could be chosen for updating: the stiffness of the LVL, concrete and cladding elements. To choose suitable updating parameters, a sensitivity analysis was performed and only parameters resulting in large sensitivities were considered. In choosing the updating parameters, the perceived variability in the mechanical characteristics was also taken into account. The elastic modulus was used in updating as a parameter. However, any increase/decrease in the elastic modulus of the materials indicated in updating could well be due to an error in the material properties, or section properties, or boundary and connectivity condition modeling.

Table 5 shows a comparison between the frequencies and mode shapes (using MAC) identified by forced vibration testing and those identified by the FE model before and after updating. While only Mode 1 and 3 were considered during updating, improvement in all fours frequencies can be observed. The mean relative difference between the four frequencies dropped from $7.4 \%$ to $3.0 \%$ as the result of updating. Also, the overall agreement in MAC values improved markedly from $52 \%$ to $71 \%$ before and after updating, respectively. The changes in the final element model parameters can be summarized as follows. The elastic modulus of the LVL increased by $9 \%$ indicating that the LVL members were stiffer than anticipated. The concrete stiffness increased by $39 \%$, which is a relatively large increase but could be due to a combination of the concrete being stronger than its nominal 28 day strength, the concrete floors being poured thicker than what the drawings indicated, and/or some composite action developing between the concrete topping and supporting timber members. The stiffness of the cladding dropped by $81 \%$. The plausible reasons for that are the cladding not being fully fixed to the structural elements, presence of large openings (e.g. for windows), and/or lower Young's modulus.

\section{CONCLUSIONS}

An innovative three-story EXPAN timber building, using self-centering, post-tensioned timber shear walls as the main horizontal load resisting system and lightweight non-composite timber-concrete floors, has been extensively instrumented for continuous monitoring and also subjected to a number of dynamic tests. The continuous monitoring system measures both slowly varying structural responses due to timber creep and fast dynamic responses due to excitations such as seismic and wind and floor vibrations due footfall loading. To that end, the monitoring system comprises about 90 channels of data from strategically positioned sensors measuring structural and ground accelerations, wind speed, static and dynamic displacements, strains, temperature and humidity.

Monitoring of long-term deformations and behaviors confirmed that they are significantly dependent on temperature and to some extent on humidity. Pres-stress loses between $10 \%$ and $20 \%$ were observed. Long-term beam deformations were up to $4 \mathrm{~mm}$.

A series of ambient and forced dynamic tests have been conducted on the building at different construction stages and experimental modal identification carried out. These enabled to trace and quantify the effect of the various structural and non-structural components, e.g. floor diaphragms, roof, shear wall post-tensioning and cladding on the building dynamics. It was observed that the floors, roof and post-tensioning increased the fundamental mode frequency by $123 \%$ and the second mode frequency by $18 \%$. Cladding increased the modal frequencies by $24 \%$ and $17 \%$, respectively. The damping ratios for the complete structure at low level elastic response were found to be between $1.6 \%$ and $2.4 \%$. For the complete building several seismic response records from the permanent monitoring system were available and system identifications results from these were compared with the forced vibration testing. The frequencies were generally similar, but damping ratios identified from the seismic response were clearly larger, between $3.5 \%$ and $4.5 \%$.

A detailed FE model was crated and updated using a sensitivity-based method. Updating results helped to clarify the contribution to structural stiffness from several structural and non-structural elements. It was found that the LVL members contribute similarly to the initial assumption, concrete floor are significantly stiffer (39\%), but cladding contributes very little ( $80 \%$ less than initially assumed). 
Return to your MySPIE To Do List at http://myspie.org and approve or disapprove this submission. Your manuscript will not be published without this approval. Please contact author_help@spie.org with any questions or concerns.

\section{ACKNOWLEDGEMENTS}

The New Zealand Ministry of Agriculture and Forestry funded the initial instrumentation with the generous co-operation of NMIT and their contractors and consultants. We also acknowledge GNS Science who funded and installed the dynamic instrumentation and provided the data. M. Worth was supported by MAF funding to Professor of Timber Design P. Quenneville.

\section{REFERENCES}

1. Filiatrault, A., Isoda, H. and Folz, B., "Hysteretic damping of wood framed buildings," Engineering Structures 25 461-471 (2003).

2. Mosalam, K. M. and Mahin, S. A., "Seismic evaluation and retrofit of asymmetric multi-story wood-frame building," Journal of Earthquake Engineering 11 (6), 968-986 (2007).

3. Filiatrault, A., Fischer, D., Folz, B. and Uang, C., "Seismic testing of two-story wood frame house: Influence of wall finish materials," Journal of Structural Engineering, ASCE 128 (10), 1337-1345 (2002).

4. Camelo, V. S., Dynamic characteristics of woodframe buildings. 2003, California Institute of Technology: Pasadena. p. 143.

5. Sutoyo, D., Hysteretic characteristics of wood-frame structures under seismic motions. 2009, California Institute of Technology: Pasadena. p. 151.

6. Filiatrault, A., Christovasilis, I. P., Wanitkorkul, A. and Van De Lindt, J. W., "Experimental seismic response of a full-scale light-frame wood building," Journal of Structural Engineering, ASCE 136 (3), 246-254 (2010).

7. van de Lindt, J. W., Pryor, S. E. and Pei, S., "Shake table testing of a full-scale seven-story steel-wood apartment building," Engineering Structures 33 757-66 (2011).

8. Ellis, B. R. and Bougard, A. J., "Dynamic testing and stiffness evaluation of a six-storey timber framed building during construction," Engineering Structures 23 (10), 1232-1242 (2001).

9. Filiatrault, A. and Folz, B., "Performance-based seismic design of wood framed buildings," Journal of Structural Engineering 128 (1), 39-47 (2002).

10. Pang, W. and Rosowsky, D. V., "Direct displacement procedure for performance-based seismic design of mid-rise wood-framed structures," Earthquake Spectra 25 (3), 583-605 (2009).

11. Pavic, A. and Reynolds, P., "Vibration serviceability of long-span concrete building floors. Part 1: Review of background information," Shock and Vibration Digest 34 (3), 191-211 (2002).

12. Aalami, B. O., Vibration design of concrete floors for serviceability, ADAPT Corporation, (2008).

13. Andriacchi, T. P., Ogle, J. A. and Galante, J. O., "Walking speed as a basis for normal and abnormal gait measurements," Journal of Biomechanics 10 (4), 261-268 (1977).

14. Hechler, O., Feldmann, M., Heinemeyer, C. and Galanti, F., Design guide for floor vibrations. 2008, Eurosteel 2008: Graz, Austria. p. 6.

15. Matsumoto, Y., Sato, S., Nishioka, T. and Shiojiri, H., "A study on dynamic design of pedestrian over-bridges," Transactions of the Japan Society of Civil Engineers 4 50-51 (1972).

16. Matsumoto, Y., Nishioka, T., Shiojiri, H. and Matsuzaki, K., "Dynamic design of footbridges," IABSE Proceedings P-17-78 (78), 1-15 (1978).

17. Leonard, D. R., "Human tolerance levels for bridge vibrations," TRRL Report No. 34 (1966).

18. Bachmann, H., Pretlove, A. J. and Rainer, H., "Dynamic forces from rhythmical human body motions," Vibration Problems in Structures: Practical Guidelines (1995).

19. Samarajiva, P. and Choudhuri, D., "Vibration study of a proposed fitness center adjacent to a server room," Proc. Proceedings of the Congress of Forensic Engineering 318-324.

20. Salyards, K. A., Hanagan, L. M. and Kim, C. A., "A unique vibration serviceability case study of a complex structure," Proc. AEI 2006: Building Integration Solutions - Proceedings of the 2006 Architectural Engineering National Conference, 33 (2006).

21. Huston, D. R., Esser, B., Plumpton, J. O. and Zhao, X., "Monitoring of microfloor vibrations in a new research building," Proc. Proceedings of SPIE - The International Society for Optical Engineering, 237-245 (2002).

22. Newcombe, M. P., Pampanin, S. and Buchanan, A. H., "Design, fabrication and assembly of a two-storey posttensioned timber building," Proc. World Conference on Timber Engineering 2010, Trentino, Italy2010). 
Return to your MySPIE To Do List at http://myspie.org and approve or disapprove this submission. Your manuscript will not be published without this approval. Please contact author_help@spie.org with any questions or concerns.

23. Uma, S., King, A., Cousins, J. and Gledhill, K., "The GeoNet building instrumentation programme," Bulletin of the New Zealand Society for Earthquake Engineering in press (2011).

24. Meo, M. and Zumpano, G., "On the optimal sensor placement techniques for a bridge structure," Engineering Structures 27 (10), 1488-1497 (2005).

25. Kammer, D. C., "Sensor placement for on-orbit modal identification and correlation of large space structures," Journal of Guidance, Control, and Dynamics 14 (2), 251-259 (1991).

26. Kammer, D. C. and Tinker, M. L., "Optimal placement of triaxial accelerometers for modal vibration tests," Mechanical Systems and Signal Processing 18 (1), 29-41 (2004).

27. Omenzetter, P., Morris, H., Worth, M., Kohli, V. and Uma, S., "Long term monitoring and field testing of an innovative multi-storey timber building," Proc. Proceedings of SPIE's Smart Structures and Materials/Nondestructive Evaluation and Health Monitoring, 798335-1-14 (2011).

28. Stanton, J., Eberhard, M. and Barr, P., "A weighted stretched wire system for monitoring deflections," Engineering Structures 25 347-357 (2003).

29. International Organization for Standardization, ISO2631-1:1997(E): Mechanical vibration and shock - evaluation of human exposure to whole body vibration, part 1: General requirements, International Organization for Standardization, Geneva, Switzerland (1997).

30. International Organization for Standardization, ISO10137:2007(E): Bases for design of structures - serviceability of buildings and walkways against vibrations, International Organization for Standardization, Geneva, Switzerland (2007).

31. Smith, A. L., Hicks, S. J. and Devine, P. J., SCI publication P354: Design of floors for vibrations: A new approach, Steel Construction Institute, Silwood Park, UK (2009).

32. Peeters, B. and de Roeck, G., "Stochastic system identification for operational modal analysis: A review," Journal of Dynamic Systems, Measurement, and Control 123 (4), 659-667 (2001).

33. Gentile, C. and Gallino, N., "Ambient vibration testing and structural evaluation of an historic suspension footbridge," Advances in Engineering Software 39 (4), 356-366 (2008).

34. Peeters, B., System identification and damage detection in civil engineering. 2000, Katholieke Universiteit Leuven: Leuven. p. 238.

35. Friswell, M. I. and Mottershead, J. E., Finite element model updating in structural dynamics, Kluwer Academic Publishers, Dordrecht (1995). 